\title{
Effectiveness Comparison of Green Tea, Probiotic, and Chlorhexidine Mouthrinses Against Streptococcus mutans in 12-15 Years Old Children in Medan City
}

\author{
Siti Salmiah ${ }^{1 *}$, Khairunnisa Khairunnisa ${ }^{2}$, Efranita Ndruru ${ }^{3}$, Annisa Farahdiba ${ }^{4}$ \\ ${ }^{1}$ Department of Pediatric Dentistry, Faculty of Dentistry, University of Sumatera Utara Jl. Alumni No.2 Kampus \\ USU Medan Sumatera Utara, Indonesia 20155 \\ ${ }^{2}$ Department of Pharmacology, Faculty of Pharmacy, University of Sumatera Utara Jl. Tri Dharma No. 5,
}

Kampus USU Medan Sumatera Utara, Indonesia 20155

${ }^{3}$ Department of Pediatric Dentistry, Faculty of Dentistry, University of Sumatera Utara Jl. Alumni No.2 Kampus USU Medan Sumatera Utara, Indonesia 20155

${ }^{4}$ Department of Pediatric Dentistry, Faculty of Dentistry, University of Sumatera Utara Jl. Alumni No.2 Kampus USU Medan Sumatera Utara, Indonesia 20155

Corresponding Author. Email: siti.salmiah@usu.ac.id

\begin{abstract}
Plaque control is an effective way to prevent caries and periodontal disease, one of which is in the form of a mouthrinses such as green tea, probiotics and chlorhexidine. This type of research is a quasi experimental, comprised 30 healthy children of age group of 12-15 years. The subjects were assigned into three groups. Streptococcus mutans count will be examined in the microbiology laboratory at baseline and $14^{\text {th }}$ day. The results showed that there was a difference in effectiveness between three groups that is green tea group, probiotic group, and chlorhexidine $0.2 \%$ group at the end of $14^{\text {th }}$ days. Paired $\mathrm{T}$ test showed that there was a statistically significant difference in the mean on Streptococcus mutans colony count in the green tea, probiotic, and chlorhexidine $0.2 \%$. Probiotic mouthrinses is more effective than green tea and chlorhexidine $0.2 \%$ mouthrinses to reduced Streptococcus mutans colony counts in children aged 12-15 years old in Medan City and potensially safe anti-plaque agent in comparison to chlorhexidine.
\end{abstract}

Keywords: Streptococcus mutans, green tea, probiotic, and chlorhexidine.

\section{INTRODUCTION}

The Indonesian public's awareness of the importance of having healthy teeth and mouth quality is still lacking, as indicated by the prevalence of an average Indonesian population experiencing oral and dental problems of $57.6 \%$. Based on Riskesdas 2013, children with oral problems are estimated around $24.8 \%$ for 12 years old and $23.1 \%$ for 15 years old, ${ }^{1}$ while Riskesdas 2018 stated that $93 \%$ of early childhood, namely on the range of 5-6 years old, experienced primary dental caries and only 7\% of children in Indonesia are free from caries problems. ${ }^{2}$ One type of microorganism that plays a primary role in the formation and accumulation of plaque, hence the occurrence of caries, is Streptococcus mutans. ${ }^{3,4}$ Plaque control, which can be used either mechanically or chemically, is an effective way to prevent caries and periodontal disease. One of the antimicrobial agents that often being used as an anti-plaque agent is in the form of a mouthwash. $5,6,7$

Chlorhexidine, generally in the form of gluconate, is a mouthrinse that has a bactericidal or bacteriostatic effect, depends on its concentration. Balagopal S et al. in 2013 stated that chlorhexidine is capable of reducing the number of Streptococcus mutans. ${ }^{8,9,10}$ Other alternatives that can be used as a mouthrinses are green tea and probiotic solutions. Green tea contains a source of polyphenols (Catechins) that inhibits the growth of bacteria such as Streptococcus mutans by hindering the activity of the glycosyltransferase enzyme of the bacteria $^{11,12}$. Meanwhile, according to WHO and 
FAO, probiotics are generally made using strains of Lactobacillus or Bifidobacterium. The microorganisms in these probiotics derive from lactic acid bacteria, namely bacteria that produces bacteriocins, which are bactericidal or bacteriostatic antimicrobial peptides against other bacterial species. ${ }^{13,14}$

The previous studies have shown the ability of chlorhexidine mouthrinse on reducing the number of Streptococcus mutans, but it contains chemical effects that are feared to be toxic if ingested by children and not well for frequent use. Hence, this study was carried out to compare the effect of using safe herbal ingredients, namely green tea and probiotics, on the colony forming units (CFU's) of salivary Streptococcus mutans in children.

\section{METHODS}

The type of research in this study is a quasiexperimental study. The sample for the study comprised of 30 healthy children aged 12-15 years in Medan City. Sampling was done by using purposive sampling technique.

\subsection{Inclusive Criteria}

Children aged 12-15 years with written consent from their parents, physically healthy with a healthy oral cavity condition and brushed their teeth twice a day. The subjects did not consume any flavored food and drink prior 1 hour the study began.

\subsection{Exclusive Criteria}

Children using any other commercially available probiotic products, taking medication, DMFT $\geq$ 2 , and subjects who withdrew from being the sample participants.

The participants who fulfilled the criteria were then assigned into three groups, with 10 children in each group. Participants were instructed to rinse their mouth for 60 seconds 30 minutes after brushing their teeth with $15 \mathrm{ml}$ mouthrinse. Parents' cooperation were needed to remind their children to brush their teeth and rinse their mouths for 14 days to see a comparison of the effectiveness from gargling green tea, probiotic and chlorhexidine $0.2 \%$ in reducing the number of Streptococcus mutans.
Group A : Green tea group Group B :

Probiotic group Group C:

Chlorhexidine group

On the $0^{\text {th }}$ day (pre-test), the saliva was collected in the given container for 1 minute. The saliva was then stored and brought to USU Pharmaceutical Microbiology laboratory to count the number of Streptococcus mutans. Examination of Streptococcus mutans using the TYCSB media and colony counter tools. Operators instructed and reminded each child to brush their teeth twice a day and rinse according to the divided groups for 14 days. The saliva collection was done again on the $14^{\text {th }}$ day (post-test) for the calculation of the Streptococcus mutans colony count.

\section{RESULTS}

Characteristics of the subjects based on gender were consisted of $63.3 \%$ female and $36.7 \%$ male, whilst based on age were namely $43.3 \%$ of 12 years old, $30 \%$ of 14 years old, $20 \%$ of 15 years old and $6.7 \%$ of 13 years old children. (Table 1). Paired $\mathrm{T}$ test was used to determine the difference in the mean of Streptococcus mutans colony count for the green tea group (Tong $\mathrm{Ji}$ ), the probiotic group (liprolac) and the chlorhexidine group. The results of statistical analysis showed that there was a significant difference before and after treatment in the green tea group, the probiotic group and the chlorhexidine group $(\mathrm{P}=0.05)$ (Table 2$)$.

One Way Anova test was used to determine the mean difference on Streptococcus mutans colony count before and after treatment in the green tea group (Tong $\mathrm{Ji}$ ), the probiotic group (liprolac) and the chlorhexidine group. The results of statistical analysis showed that there was a significant difference between the green tea group, the probotic group and the chlorhexidine group $(\mathrm{P}=0.05)$ (Table 3).

Post hoc test was used to determine the effectiveness of reducing the number of Streptococcus mutans before and after treatment between the green tea group (Tong $\mathrm{Ji}$ ), the probiotic group (liprolac) and the chlorhexidine group $0.2 \%$. The results of statistical analysis showed that gargling green tea was as effective as gargling with $0.2 \%$ chlorhexidine. Hence, out of the 3 groups, gargling with probiotic solutions was more effective in reducing the number of Streptococcus mutans than gargling either with green tea or chlorhexidine $0.2 \%$ (Table 4). 
Table 1: Subject characteristics based on gender and age

\begin{tabular}{clcc}
\hline Charateristic & & $\mathbf{n ( 3 0 )}$ & \%(100) \\
Male & Gender & & \\
Female & & 11 & 36.7 \\
12 & Age & 19 & 63.3 \\
13 & & 13 & 43.3 \\
14 & & 2 & 6.7 \\
15 & & 9 & 30 \\
\hline
\end{tabular}

Table 2: The mean and standard deviation of the colony forming units (CFU's) of salivary Streptococcus mutans before and after treatment

\begin{tabular}{cccc}
\hline Group & $\begin{array}{c}\text { Before Treatment } \\
(\mathbf{x} \pm \text { SD }) \\
(\mathbf{C F U} / \mathbf{m l})\end{array}$ & $\begin{array}{c}\text { After Treatment }(\mathbf{x} \pm \text { SD }) \\
(\mathbf{C F U} / \mathbf{m l})\end{array}$ & $\boldsymbol{P}$ \\
\hline Green Tea & $125.50 \pm 29.919$ & $76.20 \pm 26.695$ & $0.003^{*}$ \\
Probiotic & $203.90 \pm 112.9$ & $70.80 \pm 26.335$ & $0.013^{*}$ \\
\hline Clorhexidine & $126.40 \pm 27.395$ & $83.10 \pm 39.278$ & $0.048^{*}$ \\
\hline
\end{tabular}

*p value <0,05; Paired T test

Table 3: The mean difference of the colony forming units (CFU's) of salivary Streptococcus mutans before and after treatment

\begin{tabular}{clcc}
\hline Group & $\begin{array}{l}\text { Mean Difference } \\
(\mathbf{x} \pm \text { SD) CFU/ml }\end{array}$ & 95\% CI & $\boldsymbol{P}$ \\
\hline Green Tea & $49.30 \pm 50.855$ & $12.92 \pm 85.68$ & \\
Probiotic & $133.10 \pm 102.20$ & $59.99 \pm 206.2$ & $0.020^{*}$ \\
& & &
\end{tabular}

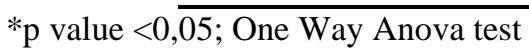

Table 4: The difference in the mean number of Streptococcus mutans between groups from the results of statistical tests (One Way Anova) which was then continued (Post Hoc)

\begin{tabular}{lcccc}
\hline Group & & $\begin{array}{l}\text { Mean Diffirence }(\mathbf{x} \pm \text { SD) } \\
(\mathbf{C F U} / \mathbf{m l})\end{array}$ & $\mathbf{9 5 \%}$ CI & $\boldsymbol{P}$ \\
\hline Green Tea & Probiotic & $-83.80 \pm 33.274$ & $-152.0 \pm-15.53$ & $0.018^{*}$ \\
& Clorhexidine & $6.000 \pm 33.274$ & $-62.27 \pm 74.27$ & 0.858 \\
& Green Tea & $83.800 \pm 33.274$ & $15.53 \pm 152.07$ & $0.018^{*}$ \\
Probiotic & Clorhexidine & $89.800 \pm 33.274$ & $21.53 \pm 158.07$ & $0.012^{*}$ \\
\hline
\end{tabular}

\footnotetext{
$* \mathrm{p}$ value $<0,05$; Post Hoc
} 


\section{DISCUSSION}

This research was conducted on 30 children consisting of three groups (green tea, probiotic, chlorhexidine) with 10 children on each group in Medan City. Based on gender distribution, the female was the largest amount with a total of 19 children $(63.3 \%)$, whilst male were 11 children $(36.7 \%)$. Based on age, the results showed that the participants were at most 12 years old with a total of 13 people (43.3\%), followed by 14 years old children with a total of 9 people (30\%), 15 years old children with a total of 6 people (20\%), and children aged 13 years with a total of 2 people $(6.7 \%)$. (Table1)

The results of statistical analysis showed that there was a significant difference before and after gargling in the green tea group, the probiotic group and the chlorhexidine group. Based on the results of the study, the mean of Streptococcus mutans colony count in the green tea group (Tong Ji) before treatment was 125.50 $\pm 29.919 \mathrm{CFU} / \mathrm{ml}$ and after treatment was $76.20 \pm 26.695 \mathrm{CFU} / \mathrm{ml}$, whilst in the probiotic group (liprolac) before and after treatment were $203.90 \pm 112.99 \mathrm{CFU} / \mathrm{ml}$ and $70.80 \pm 26.335$ $\mathrm{CFU} / \mathrm{ml}$, and in the chlorhexidine group Before and after treatment were $126.40 \pm 27.395 \mathrm{CFU} / \mathrm{ml}$ and 83,10 $\pm 39.278 \mathrm{CFU} / \mathrm{ml}$, respectively. $(\mathrm{P}=0.05) \quad$ (Table 2). These results were consistent with the research conducted by Mohan Jothika et al in 2015 regarding the effectiveness of probiotic (Darolac), chlorhexidine and fluoride mouthrinses against the number of Streptococcus mutans in vivo. In this study, the mean number of Streptococcus mutans after treatment on the 30th day were 8.71 CFU/ml in the probiotic group, 10.38 $\mathrm{CFU} / \mathrm{ml}$ in the chlorhexidine group, 19.76 $\mathrm{CFU} / \mathrm{ml}$ in the fluoride group and 70.33 $\mathrm{CFU} / \mathrm{ml}$ in the group gargling with distilled water. Mohan Jothika et al's study concluded that chlorhexidine, sodium fluoride, probiotics managed reducing the number of Streptococcus mutans but gargling with probiotic solutions is more effective so that it can be an alternative in maintaining oral hygiene. According to Mohan Jothika et al, the mechanism of decreasing the number of Streptococcus mutans occured because probiotics contain bacteria such as Lactobacillus or Bifidobacterium which do not ferment lactose and sucrose and can dominate the oral cavity even though they are temporary, thus reducing the colonization of Streptococcus mutans in saliva. ${ }^{15}$ The results of this study were also supported by Nikhe D. Nubatonis et al in 2016 regarding the effect of gargling with green tea solution in reducing plaque accumulation on the teeth of children aged 8-10 years. Based on their research, they stated that there was a difference in the mean plaque accumulation before and after gargling with green tea and chlorhexidine solutions $(\mathrm{P}=0.0001){ }^{16}$

The reduction occurred in the green tea group because it contains polyphenolic compounds which mostly consist of catechins. These catechins from green tea work to inhibit the activity of the glycotransferase enzyme, thereby detering the attachment of bacteria to the pellicle and the process of plaque formation. Polyphenols also work to inhibit the growth of microorganisms due to its ability to denature cell proteins and damage the cell membranes of microorganisms on dental plaque. ${ }^{11,16}$ This statement was also supported by Rosy Sirisha N et al's research on the effectiveness of green tea on the number of Streptococcus mutans. The results of their study showed the difference in the mean number of Streptococcus mutans in the green tea group, namely before and after treatment were $32200.0 \pm 1316.6 \mathrm{CFU} / \mathrm{ml}$ and $266000.0 \pm 1429.8 \mathrm{CFU} / \mathrm{ml}$, whilst in the chlorhexidine gargling group, before and after treatment were $31900.0 \pm 1370.3 \mathrm{CFU} / \mathrm{ml}$ and $26200.0 \pm 1316.6 \mathrm{CFU} / \mathrm{ml}$, respectively $(\mathrm{p}=0.05) .^{12}$ The statistical analysis showed that there was a statistically significant difference in the mean difference of the reduction of Streptococcus mutans colony count in the green tea group (Tong Ji) $(49.30 \pm 50.855 \mathrm{CFU} / \mathrm{ml})$ and the probiotic group (Liprolac) (133.10 $\pm 102.201 \quad \mathrm{CFU} / \mathrm{ml})$ $(\mathrm{P}=0.018)$. The results showed that there was no significant difference in the mean difference of the reduction of Streptococcus mutans colony count in the green tea group $(49.30 \pm 50.855$ $\mathrm{CFU} / \mathrm{ml})$ and the chlorhexidine group $(43.30 \pm 59.803 \mathrm{CFU} / \mathrm{ml}) \quad(\mathrm{P}=0.858)$ (Tables 3 and 4). The results also showed that there was a statistically significant difference in the mean difference of the reduction of Streptococcus mutans colony count in the probiotic group $(133.10 \pm 102.201 \mathrm{CFU} / \mathrm{ml})$ and the chlorhexidine group (43.30 $\pm 59.803 \mathrm{CFU} / \mathrm{ml})(\mathrm{P}=0.012)$ (Tables 3 and 4). These results were consistent with Rosy Sirisha N et al's study on the effectiveness of green tea on the Streptococcus mutans count. Based on this study, there was no difference in the mean difference of Streptococcus mutans colony count in the green tea group and chlorhexidine group $(\mathrm{P}=0.1988)$.

\section{CONCLUSION}

The conclusion of this study is that there are significant differences in the effectiveness of the probiotic solution (Liprolac), green tea (Tong Ji) and chlorhexidine $0.2 \%$ in reducing the number of Streptococcus mutans on children aged 12-15 
years in Medan. However, researchers found an alternative plaque control that is effective and safe, especially for children, namely probiotics mouthrinse, which contains non-pathogenic bacteria such as Bifidobacterium and Lactobacillus acidophillus which can inhibit the growth of pathogenic bacteria by producing bacteriocins and through a combination of systemic and local immune systems and also the body's defense mechanisms.

\section{ACKNOWLEDGMENT}

This study was partially supported University of Sumatera Utara Talent Research 2020.

\section{AUTHOR'S CONTRIBUTION}

Author 1 (Siti Salmiah) and author 2 (Khairunnisa Khairunnisa) conceived and designed the analysis, collected the data, and contributed data or analysis tools.

Author 3 (Efranita Ndruru) and Author 4 (Annisa Farahdiba) perfomed the analysis and wrote paper.

\section{CONFLICT OF INTEREST}

Nil

\section{REFERENCES}

1. Kemenkes RI. Riset kesehatan dasar tahun 2018. Jakarta: Kemenkes RI2018;99-103.

2. Kemenkes RI. Riset kesehatan dasar tahun 2013. Jakarta: Kemenkes RI2013;110-19.

3. Guo E, Ma N, Yang F, Yu J, Yuan X, Zhang Y, et al. Caries experience and its association with weight status among 8- year-old children in Qingdao, China. J Int Soc Prev Community Dent 2015;5(1):52- 8 .

4. Lemos JA, Quivey R G, Koo H. Streptococcus mutans: a new gram- positive paradigm. SGM J 2013:436-445.

5. Hermina V. Efektivitas metode pengajaran cara menyikat gigi terhadap penurunan indeks plak anak usia 3-5 tahun. Dentika Dent J2010;15(1):42-5.

6. Malhotra R, Grover V, KapoorA, Saxena D. Comparison of the effectiveness of a commercially available herbal mouthrinse with chlorhexidine gluconate at the clinical and patient level. J Ind Soc Perio.2011;15(4):349-52.

7. Mandal A, Singh DK, Siddiqui H, et al. New dimensions in mechanical plaque control: an overview. Indian J Dent Sci 2017; 9(2):133-9.

8. Balagopal S, Arjunkumar R. Chlorhexidine: the golden standard antiplaque agent. J Pharm Sci \&Res 2013;5(12):270-4.
9. Faria G, Jr M S, Santos B M, Ito I Y. The effect of chlorhexidine on plaque index and mutans Streptococci in orthodontic patients: A pilot study. OJST 2013;3:323-8.

10. Patabang W, Leman M, Maryono J. Perbedaan jumlah pertumbuhan koloni bakteri rongga mulut sebelum dan sesudah menggunakan obat kumur yang mengandung chlorhexidine. $\mathrm{J}$ Ilmiah Farmasi 2016;5(1):26-31.

11. Reygaert WC. The antimicrobial possibilities od green tea. J Frontiers in Microbiology 2014; 5:1-8.

12. Rosy SN, Srinivas R,Vikram SB, et al. Effect of Green Tea on Streptococcus mutans Counts: A Randomised Control Trail. Clin Diagnostic Research J 2014;8(11):128-130.

13. Parthkumar K.Thakkar, Md Imranulla, P.G.Naveen Kumar. Effect of probiotic mouthrinse on dental plaque accumulation: A randomized controlled trial. Dent Med Research2013;1(1):7-12.

14. Srivastava S, Saha S, Kumari M,Mohade

$\mathrm{S}$. Effect of probiotic curd on salivary $\mathrm{pH}$ and Streptococcus mutans: A double blind parallel randomized controlled trial. Clin Diagnostic Research J 2016;10(2):13-6.

15. Mohan Jothika, P.Pranav Vanajassun, Battu Somehwar. Effectiveness of probiotic, chlorhexidineand fluoride mouthwash against Streptococcus mutans- Randomized, single blind, in vivo study. Int $\mathbf{J}$ Society of Preventive and Community Dent2015;5(1):448.

16. Nubatonis N D, Gunawan $\mathrm{P} N$, Wuisan J. Pengaruh berkumur larutan teh hijau dalam menurunkan akumulasi plak pada gigi anak usia 8-10 tahun. J e-Gigi 2016 4(2): 183. 